\title{
Ruokinnan intensiivisyyden vaikutus maitorotuisten hiehojen kasvuun ja ruhon laatuun
}

\author{
Päivi Lamminen ${ }^{1)}$, Arto Huuskonen ${ }^{1)}$ ja Päivi Volanto ${ }^{2)}$ \\ ${ }^{1)}$ MTT, Pohjois-Pohjanmaan tutkimusasema,92400 Ruukki, etunimi.sukunimi@mtt.fi \\ ${ }^{2)}$ Rehuraisio Oy, PL 101, 21201 Raisio, etunimi.sukunimi@raisiogroup.com
}

\section{Tiivistelmä}

Teurashiehojen ruokinnan tavoite on tuottaa hyvin kasvavia mutta mahdollisimman vähän rasvoittuvia ruhoja. Teurashiehojen ruokinta on yleensä rajoitettua, sillä runsas energiansaanti nopeuttaa kasvua, mutta lisää eläinten rasvaisuutta. Tämän tutkimuksen tarkoituksena oli selvittää väkirehuruokinnan voimakkuuden vaikutusta maitorotuisten hiehojen kasvuun ja teurastuloksiin.

Ruokintakoe toteutettiin MTT:n Pohjois-Pohjanmaan tutkimusasemalla. Koe-eläimet (yhteensä 30 kpl maitorotuisia hiehoja) olivat tutkimusasemalla alkukasvatettuja lehmävasikoita. Koeruokinnat erosivat väkirehuruokinnan koostumuksen ja intensiteetin osalta (Taulukko 1). Ensimmäisellä jaksolla (eläinten ikä 2vk-3kk) kaikki eläimet saivat vapaasti väkirehuna teollista täysrehua (Mullin-Herkku 1). Kolmannesta elinkuukaudesta eteenpäin ensimmäisen käsittelyn eläimet saivat väkirehuna 2 kg ohraa / päivä (OHRA2ryhmä). Toisen käsittelyn eläimet saivat vastaavasti 2 kg Mullin-Herkku 1 -täysrehua (MH2-ryhmä). Kolmannella käsittelyllä olleet hiehot saivat väkirehuna 4 kg Mullin-Herkku 1 -täysrehua (MH4-ryhmä). Kaikki ruokintaryhmät saivat ensimmäisellä jaksolla säilörehua vapaasti, toisella jaksolla (3 kk - 9 kk) säilörehua annettiin maksimissaan $3 \mathrm{~kg}$ ka / pv ja viimeisessä jaksossa (9 kk - teurastus) maksimissaan 4 kg ka / pv. Kuivaa heinää annettiin kokeen ajan vapaasti. Koe toteutettiin erillisruokintana. Säilörehuna oli hyvälaatuinen nurmisäilörehu (D-arvo keskimäärin 68).

Taulukko 1. Ruokintakokeen kolme erilaista väkirehuruokintaa. (MH1 = Mullin-Herkku 1).

\begin{tabular}{|c|c|c|c|}
\hline & Jakso 1 & Jakso 2 & Jakso 3 \\
\hline Käsittely & 2vk - 3kk & 3kk - 9kk & 9kk - teurastus \\
\hline 1. & vapaasti (MH1) & $2 \mathrm{~kg}(\mathrm{ohra})$ & $2 \mathrm{~kg}(\mathrm{ohra})$ \\
\hline 2. & vapaasti (MH1) & $2 \mathrm{~kg}(\mathrm{MH} 1)$ & $2 \mathrm{~kg}(\mathrm{MH} 1)$ \\
\hline 3. & vapaasti (MH1) & vapaasti, max. 4kg (MH1) & $4 \mathrm{~kg}(\mathrm{MH} 1)$ \\
\hline
\end{tabular}

Ikävälillä 3-6 kuukautta (eläimet ryhmäkarsinoissa) hiehojen kuiva-aineen syönti ja energian saanti oli suurinta MH4-ruokinnalla. Tämä johtui luonnollisesti suuremmasta tarjotusta väkirehuannoksesta. Vastaavasti säilörehun syönti oli vähäisintä MH4-ruokinnalla. Suuremmasta energian saannista johtuen hiehot myös kasvoivat em. jaksolla parhaiten MH4-ruokinnalla.

Parsikasvatuskaudella (6 kuukauden iästä teurastukseen) MH4-ryhmän eläimet söivät noin kg:n enemmän kuiva-ainetta päivässä kuin MH2- ja OHRA2-ryhmien eläimet (7,1 vs. 6,1 kg ka/pv) (p<0.001). Suurempi väkirehuannos näkyi myös lisääntyneenä energian saantina, sillä MH4-ryhmä sai päivässä yli rehuyksikön verran enemmän energiaa kuin OHRA2- ja MH2-ryhmät (7,1 vs. 5,9 ry/pv) ( $<<0.001)$. Väkirehuruokinnan voimakkuus vaikutti myös kasvutuloksiin, sillä MH4-ryhmän hiehot kasvoivat selkeästi paremmin (päiväkasvu 1065 g/pv) kuin MH2- (901 g/pv) tai OHRA2-ryhmän (876 g/pv) hiehot $(\mathrm{P}<0.001)$. MH2- ja OHRA2-ryhmien välillä ei ollut merkitseviä eroja kasvuluvuissa. Hiehojen keskimääräinen teuraspaino oli 231 kilogrammaa. Kaikilla ruokinnoilla päästiin tavoiteltuun teuraspainohaarukkaan (220-240 kg). Väkirehun päivittäisen annosmäärän nostaminen 2 kg:sta 4 kg:n ei vaikuttanut ruhojen rasvoittumiseen (keskimäärin 3,4 EUROP-luokituksella).

Asiasanat: naudanlihantuotanto, hiehot, ruokinta, rehut, väkirehut, kasvu, ruhon laatu 


\section{Johdanto}

Keskeinen tavoite teurashiehojen ruokinnassa on tuottaa nopeasti kasvavia mutta samalla mahdollisimman vähän rasvoittuvia ruhoja. Lihantuotantoon kasvatettavien hiehojen ruokinta on yleensä rajoitettua, sillä runsas energiansaanti nopeuttaa kasvua, mutta lisää eläinten rasvaisuutta. Ruokinnan rajoittaminen tapahtuu yleensä joko antamalla rehuja vähemmän kuin eläimet söisivät tai rajoittamalla rehuannoksen energiapitoisuutta. Rinteen ym. (1998) tutkimuksessa kohtuullinen väkirehulisä (27 \% rehuannoksen kuiva-aineesta) nopeutti hiehojen kasvua selvästi pelkkään säilörehuruokintaan verrattuna, mutta ei lisännyt ruhojen rasvoittumista liharoturisteytyshiehoilla. Suurin osa Suomessa viime aikoina tehdyistä lihahiehojen ruokintakokeista onkin toteutettu joko liharoturisteytyshiehoilla (Suvitie ja Manninen 1992. Manninen ym. 1998, Rinne ja Ojajärvi 1998) tai puhtailla liharotueläimillä (Manninen ym. 2002, 2004). Lypsyrotuisilla hiehoilla tehdyt tutkimukset ovat sekä Suomessa että muualla käsitelleet ensisijaisesti ruokintavaihtoehtoja myöhemmän maidontuotannon kannalta (esim. Sejrsen ym. 1982, Foldager ja Sejrsen 1991, Mäntysaari 2001) tai eläinten sosiaalista käyttäytymistä (Raussi ym. 2005). Mäntysaaren (1993) tutkimuksessa päiväkasvun lisääntyminen 650 grammasta 850 grammaan ei vaikuttanut ay-rotuisten hiehojen ruhon laatuun, mutta kyseisessä tutkimuksessa hiehot teurastettiin jo alle $220 \mathrm{~kg}: n$ elopainossa. Nykyään teurashiehot kasvatetaan yli 400 kg:n elopainoon, mikä lisää ruhojen rasvoittumisriskiä. Tämän tutkimuksen tarkoituksena oli selvittää väkirehuruokinnan voimakkuuden vaikutusta maitorotuisten hiehojen kasvuun ja teurastuloksiin, kun hiehot kasvatetaan selkeästi yli 200 kg:n teuraspainoon. Tutkimus toteutettiin MTT:n, Rehuraisio Oy:n ja Atria Oyj:n yhteishankkeena.

\section{Aineisto ja menetelmät}

Hiehojen ruokintakoe toteutettiin Maa- ja elintarviketalouden tutkimuskeskuksen Pohjois-Pohjanmaan tutkimusasemalla Ruukissa. Ruokintakoe alkoi maaliskuussa 2004 ja päättyi elokuussa 2005, jolloin viimeiset koe-eläimet teurastettiin. Koe-eläimet (yhteensä $30 \mathrm{kpl}$ maitorotuisia hiehoja) olivat PohjoisPohjanmaan tutkimusasemalla alkukasvatettuja lehmävasikoita, jotka olivat 3 kk:n ikäisiä ruokintakokeen alkaessa. Alkukasvatus tapahtui 5 vasikan ryhmissä ryhmäkarsinoissa. Juottokaudella vasikat saivat 6 litraa teollista juomarehua ja lisäksi tarjolla oli vapaasti teollista täysrehua (Mullin-Herkku1) sekä hyvälaatuista nurmisäilörehua ja kuivaa heinää. Varsinainen koeruokinta aloitettiin eläinten ollessa 3 kuukauden iässä, jolloin vasikat jaettiin elopainon perusteella kolmeen lohkoon ja arvottiin lohkoista satunnaisesti eri ruokintaryhmiin. Eläimet kasvatettiin 6 kuukauden ikään saakka ryhmäkarsinoissa, minkä jälkeen ne siirrettiin parsikasvatukseen.

Koeruokinnat erosivat toisistaan väkirehuruokinnan koostumuksen ja intensiteetin osalta (Taulukko 1). Ensimmäisellä jaksolla (eläinten ikä 2vk-3kk) kaikki eläimet saivat vapaasti väkirehuna ollutta teollista täysrehua (Mullin-Herkku 1). Kolmannesta kuukaudesta eteenpäin ensimmäisen käsittelyn eläimet saivat väkirehuna 2 kg ohraa / päivä (OHRA2-ryhmä). Toisen käsittelyn eläimet saivat vastaavasti väkirehuna 2 kg Mullin-Herkku 1 -täysrehua (MH2-ryhmä). Kolmannella käsittelyllä olleet hiehot saivat väkirehuna 4 kg Mullin-Herkku 1 -täysrehua / päivä (MH4-ryhmä).

Taulukko 1. Ruokintakokeen kolme erilaista väkirehuruokintaa. (MH1 = Mullin-Herkku 1).

\begin{tabular}{|c|c|c|c|}
\hline & Jakso 1 & Jakso 2 & Jakso 3 \\
\hline Käsittely & 2vk - 3kk & 3kk - 9kk & 9kk - teurastus \\
\hline 1. & vapaasti (MH1) & $2 \mathrm{~kg}$ (ohra) & $2 \mathrm{~kg}(\mathrm{ohra})$ \\
\hline 2. & vapaasti (MH1) & $2 \mathrm{~kg}(\mathrm{MH} 1)$ & $2 \mathrm{~kg}(\mathrm{MH} 1)$ \\
\hline 3. & vapaasti (MH1) & vapaasti, max. 4kg (MH1) & $4 \mathrm{~kg}(\mathrm{MH} 1)$ \\
\hline
\end{tabular}

Kaikki ryhmät saivat ensimmäisellä jaksolla säilörehua vapaasti, toisella jaksolla (3 kk - 9 kk) säilörehua annettiin maksimissaan $3 \mathrm{~kg} \mathrm{ka} / \mathrm{pv}$ ja viimeisessä jaksossa (9 kk - teurastus) säilörehua annettiin maksimissaan $4 \mathrm{~kg}$ ka / pv. Kuivaa heinää annettiin vapaasti kaikissa ryhmissä. Koe toteutettiin erillisruokintana. Säilörehuna oli hyvälaatuinen nurmisäilörehu. Ruokinnassa huolehdittiin myös eläinten kivennäisaineiden sekä vitamiinien tarpeesta. Kivennäisenä käytettiin MulliMelli-kivennäistä 100 grammaa eläintä kohti päivässä. Kivennäisen lisäksi annettiin ADE-vitamiinitäydennys.

Säilörehusta tehtiin kuiva-ainemääritys kahdesti viikossa tarjotun rehuannoksen laskemista varten ja rehusta otettiin edustava näyte siirtoajokerroittain. Näytteet yhdistettiin vastaamaan kunkin ruokintajakson (4 viikkoa) aikana syötettyä rehua. Ohran, heinän, ja täysrehun analyysinäytteenä 
käytettiin kahden ruokintajakson aikana kerätyistä osanäytteistä yhdistettyjä kokonaisnäytteitä. Rehujen kemiallinen koostumus määritettiin Ahvenjärven (2000) kuvaamalla tavalla. Säilörehusta määritettiin myös käymislaatu (pH, kokonaistyppi, liukoinen typpi, ammoniumtyppi, vesiliukoiset hiilihydraatit, haihtuvat rasvahapot ja maito- sekä muurahaishappo). Käymislaadun määritykset tehtiin Valio Oy:ssä käytössä olevalla puristenestetitraukseen pohjautuvalla laatumäärityksellä (Moisio ja Heikonen 1989). Säilörehun D-arvo määritettiin NIR-menetelmällä (Nousiainen ym. 2004).

Rehujen rehuarvot laskettiin määritettyjen analyysien ja rehutaulukosta saatujen ravintoaineiden sulavuuksien perusteella. Rehujen rehuyksikköarvot laskettiin jakamalla ME-arvo 11,7:llä (Tuori ym. 2000). Rehujen valkuaisarvot laskettiin ohutsuolesta imeytyvinä aminohappoina (OIV) (Tuori 1992). Säilörehujen syönti-indeksi määritettiin Nousiaisen ja Huhtasen (2002) kuvaamalla tavalla.

Hiehot punnittiin kokeen alussa, kokeen aikana neljän viikon välein ja kokeen lopussa. Samalla eläinten rinnanympärys, pituus ja säkäkorkeus mitattiin. Hiehojen teuraspainotavoite oli 220-240 kg. Tavoitepainon saavuttamiseksi eläimet teurastettiin kolmessa erässä (toukokuussa, heinäkuussa ja elokuussa 2005). Teurastuksen yhteydessä ruhojen laatu määriteltiin luokittelemalla ruhojen lihakkuus ja rasvaisuus EUROP-luokituksen mukaisesti.

Ruokinnoista määritettiin lisäksi ravintoaineiden näennäinen in vivo-sulavuus AIA-menetelmällä (Keulen ja Young 1977). Sulavuuskoe tehtiin joulukuussa 2004, jolloin eläimet olivat keskimäärin 9 kuukauden ikäisiä ja painoivat keskimäärin 222 kg. Sulavuuskokeen kestoaika oli viisi vuorokautta, ja sen aikana kerätyistä rehu- ja sontanäytteistä analysoitiin sekundäärinen kuiva-aine, tuhka, raakavalkuainen ja NDF-kuitu Ahvenjärven (2000) kuvaamalla tavalla.

Koetulosten tilastollinen käsittely tehtiin SAS-ohjelmiston GLM -proseduuria käyttäen. Koekäsittelyiden mahdolliset erot testattiin varianssianalyysillä ja koekäsittelyjen keskiarvojen erojen tilastollinen merkitsevyys testattiin Tukeyn testillä. Karsinakasvatuskauden (eläinten ikä 3 kk - 6 kk) tuloksia testatessa havaintoyksikkönä käytettiin karsinaa. Loppukasvatuskaudella (6 kuukauden iästä teurastukseen hiehot olivat parsissa ja tilastollisessa testauksessa voitiin käyttää havaintoyksikkönä eläintä. Loppukasvatuskauden tuloksia analysoitaessa testauksen koemalli oli lohkoittain satunnaistettu koe. Koemalli: $\mathrm{y}_{\mathrm{ij}}=\mu+$ ruokinta $_{\mathrm{i}}+$ lohko $_{\mathrm{j}}+\mathrm{e}_{\mathrm{ij}}$. Karsinakauden tuloksia testattaessa mallissa ei voitu käyttää lohkotekijää, koska sama havaintoyksikkö (karsina) sisälsi eläimiä useammasta lohkosta.

\section{Tulokset ja tulosten tarkastelu}

Rehujen kemiallinen koostumus, rehuarvot sekä säilörehun säilönnällinen laatu esitetään taulukossa 2. Säilörehun säilönnällinen laatu oli hyvä käymishappojen sekä ammonium- ja liukoisen typen perusteella mitattuna. Myös säilörehun sulavuus oli hyvä (D-arvo keskimäärin 68 kokeen aikana).

Taulukko 2. Ruokintakokeen rehujen kemiallinen koostumus, rehuarvot sekä säilörehun säilönnällinen laatu.

\begin{tabular}{|l|c|c|c|c|}
\hline & Säilörehu & Heinä & Mullin-Herkku 1 & Ohra \\
\hline Kuiva-aine, g/kg & 252 & 830 & 875 & 888 \\
\hline Kuiva-aineessa, g/kg ka & & & & \\
\hline$-\quad$ tuhka & 77 & 44 & 205 & 135 \\
\hline$\quad$ raakavalkuainen & 164 & 62 & 249 & 257 \\
\hline$\quad$ NDF-kuitu & 504 & 675 & 52 & 34 \\
\hline raakarasva & 49 & 21 & 1,08 & 113 \\
\hline OIV, g/kg ka & 0,93 & 0,75 & 25 & -38 \\
\hline PVT, g/kg ka & 85 & 74 & & 60,1 \\
\hline Hehtolitrapaino, kg/hl & 19 & -63 & & \\
\hline D-arvo & & & & \\
\hline Syönti-indeksi & 68 & 59 & & \\
\hline pH & 100 & & & \\
\hline Kokonaistypestä, g/kg N & 3,93 & & & \\
\hline$\quad$ NH3-N & & & & \\
\hline$\quad$ Liukoinen-N & 453 & & & \\
\hline Maitohappo, g/kg ka & 60 & & & \\
\hline Haihtuvat rasvahapot, g/kg ka & 15 & & & \\
\hline Sokerit, g/kg ka & 62 & & & \\
\hline
\end{tabular}


Taulukossa 3 on eläinten rehun syönti, ravintoaineiden saanti ja kasvutulokset karsinakasvatuskaudelta eli ajanjaksolta, jolloin eläimet olivat $3-6$ kuukauden ikäisiä. Kokeesta jouduttiin tällä ajanjaksolla poistamaan kolme vasikkaa hengitystietulehdusoireiden vuoksi. Poistetuista eläimistä yksi oli OHRA2ruokinnalla ja kaksi MH4-ruokinnalla. Sairastapaukset eivät johtuneet koeruokinnoista.

Ikävälillä 3-6 kuukautta hiehojen kuiva-aineen syönti ja energian saanti oli suurinta MH4ruokinnalla (Taulukko 3). Tämä johtui suuremmasta tarjotusta väkirehuannoksesta. Vastaavasti säilörehun syönti oli vähäisintä MH4-ruokinnalla. Suuremmasta energian saannista johtuen hiehot myös kasvoivat parhaiten MH4-ruokinnalla. Ero ei ollut tilastollisesti merkitsevä $(\mathrm{p}<0.10)$ johtuen suuresta eläinten välisestä keskinäisestä hajonnasta. Hiehojen valkuaisen saannissa oli eroja ruokintojen välillä. Valkuaisen saanti oli suurempaa MH-ruokinnoilla kuin OHRA2-ruokinnalla.

Taulukko 3. Rehun syönti, ravintoaineiden saanti ja kasvu karsinakasvatuskaudella (eläinten ikä 3 kk - 6 kk).

\begin{tabular}{|c|c|c|c|c|c|}
\hline (2) & OHRA2 & MH2 & MH4 & $S E E^{1)}$ & $\begin{array}{c}\text { Tilastollinen } \\
\text { merkitsevyys }^{2)}\end{array}$ \\
\hline Eläinmäärä, kpl & 9 & 10 & 8 & & \\
\hline \multicolumn{6}{|l|}{ Rehun syönti, kg ka / pv } \\
\hline - Säilörehu & $1,44^{\mathrm{ab}}$ & $1,89^{\mathrm{a}}$ & $1,04^{\mathrm{b}}$ & 0,151 & * \\
\hline - $\quad$ heinä & 0,03 & 0,02 & 0,03 & 0,011 & \\
\hline - $\quad$ väkirehu & 1,67 & 1,75 & 2,94 & & \\
\hline - yhteensä & $3,14^{\mathrm{a}}$ & $3,66^{\mathrm{ab}}$ & $4,01^{\mathrm{b}}$ & 0,172 & $*$ \\
\hline - kg ka / lisäkasvukilo & 4,71 & 5,40 & 4,43 & 0,623 & \\
\hline \multicolumn{6}{|l|}{ Ravintoaineiden saanti } \\
\hline - $\quad$ ry / pv & $3,08^{\mathrm{a}}$ & $3,44^{\mathrm{ab}}$ & $3,98^{\mathrm{b}}$ & 0,160 & * \\
\hline - $\quad$ raakavalkuainen, g/pv & $503^{\mathrm{a}}$ & $722^{\mathrm{b}}$ & $804^{b}$ & 34,1 & $* *$ \\
\hline - $\quad$ OIV, g/pv & $294^{\mathrm{a}}$ & $354^{\mathrm{a}}$ & $423^{b}$ & 15,8 & $* *$ \\
\hline - $\quad$ PVT, g/pV & $12^{\mathrm{a}}$ & $143^{\mathrm{b}}$ & $127^{\mathrm{b}}$ & 11,2 & $* *$ \\
\hline Päiväkasvu, g/pv & 679 & 734 & 920 & 10,1 & \\
\hline
\end{tabular}

Taulukko 4. Rehun syönti ja ravintoaineiden saanti parsikasvatuskaudella (6 kuukauden iästä teurastukseen).

\begin{tabular}{|c|c|c|c|c|c|}
\hline & OHRA2 & MH2 & MH4 & SEE $^{1)}$ & $\begin{array}{c}\text { Tilastollinen } \\
\text { merkitsevyys }^{2)}\end{array}$ \\
\hline Eläinmäärä, kpl & 9 & 10 & 8 & & \\
\hline \multicolumn{6}{|l|}{ Rehun syönti, kg ka / pv } \\
\hline - säilörehu & 3,97 & 4,04 & 3,59 & & \\
\hline - heinä & 0,29 & 0,35 & 0,10 & & \\
\hline - väkirehu & 1,74 & 1,74 & 3,44 & & \\
\hline - $\quad$ yhteensä & $6,00^{\mathrm{a}}$ & $6,13^{\mathrm{a}}$ & $7,13^{b}$ & 0,251 & $* * *$ \\
\hline \multicolumn{6}{|l|}{ Ravintoaineiden saanti } \\
\hline - $\quad r y / p v$ & $5,88^{\mathrm{a}}$ & $5,88^{\mathrm{a}}$ & $7,05^{b}$ & 0,237 & $* * *$ \\
\hline - $\quad$ raakavalkuainen, g/pv & $907^{\mathrm{a}}$ & $1043^{b}$ & $1305^{c}$ & 40,2 & $* * *$ \\
\hline - $\quad$ OIV, g/pv & $547^{\mathrm{a}}$ & $572^{b}$ & $710^{\mathrm{C}}$ & 22,3 & $* * *$ \\
\hline - $\quad$ PVT, g/pv & $-11^{\mathrm{a}}$ & $96^{\mathrm{b}}$ & $149^{c}$ & 8,2 & $* * *$ \\
\hline
\end{tabular}

Hiehojen rehun syönti ja ravintoaineiden saanti parsikasvatuskaudella (6 kuukauden iästä teurastukseen) käyvät esille taulukosta 4. Tällä ajanjaksolla MH4-ryhmän eläimet söivät noin kilogramman enemmän kuiva-ainetta päivässä kuin MH2- ja OHRA2-ryhmien eläimet ( $<<0.001)$, mikä johtui MH4-ryhmän saamasta suuremmasta väkirehuannoksesta. OHRA2- ja MH2-ryhmien rehun syönnissä ei ollut eroa. Suurempi väkirehuannos näkyi myös lisääntyneenä energian saantina, sillä MH4-ryhmä sai päivässä yli rehuyksikön verran enemmän energiaa kuin OHRA2- ja MH2-ryhmät ( $<<0.001)$. Ryhmien välillä oli myös selkeät erot valkuaisen saannissa. OHRA2-ryhmän hiehoilla raakavalkuaisen, OIV:n ja PVT:n saanti oli merkitsevästi vähäisempää kuin MH2 ryhmän hiehoilla $(\mathrm{P}<0.001)$. Vastaavasti MH4-ryhmän hiehot saivat selkeästi enemmän valkuaista kuin $\mathrm{MH}-2$ ryhmän eläimet $(\mathrm{P}<0.001)$. Erot johtuivat $\mathrm{MH4}$-ryhmän suuremmasta väkirehuannoksesta sekä ohran Mullin-Herkku 1 -täysrehua pienemmästä 
valkuaispitoisuudesta. OIV-saanti täytti kuitenkin kaikissa ruokintaryhmissä kasvaville hiehoille asetetut OIV-suositukset (Tuori ym. 2000).

Elopainon, säkäkorkeuden, rinnanympäryksen ja pituuden kehitys kokeen aikana on esitetty taulukossa 5. Kokeen alussa hiehot olivat kolmen kuukauden ikäisiä, niiden elopaino oli keskimäärin 89 kg, säkäkorkeus $86 \mathrm{~cm}$, rinnanympärys $98 \mathrm{~cm}$ ja pituus $79 \mathrm{~cm}$. Ruokinnan voimakkuuden myötä lisääntynyt energian saanti näkyi selkeästi hiehojen elopainon kehityksessä (Taulukko 5). MH4-ryhmän hiehot olivat kokeen alkua lukuun ottamatta elopainoltaan suurempia kuin MH2- ja OHRA2-ryhmien hiehot. OHRA2- ja MH2-ryhmien välille ei muodostunut merkitseviä eroja elopainossa. OHRA2- ja MH2ryhmien välille muodostui jonkin verran numeerista eroa kokeen alkupuolella: 9 kuukauden ikään saakka MH2-ryhmän hiehot painoivat hieman enemmän kuin OHRA2-ryhmän hiehot. Tämä ero kuitenkin tasoittui ja kompensoitui kokeen aikana. Suurempi valkuaisen saanti MH2-ruokinnalla selittänee eroa kokeen alussa. Nuorella iällä (alle 250 kg:n painossa) eläimet hyötyvät lisääntyneestä valkuaisen saannista, koska niiden pötsimikrobien valkuaistuotanto ei vielä täysin riitä tyydyttämään valkuaisen tarvetta. Alkuvaiheen lisävalkuaisesta aiheutuva hyöty on kuitenkin kyseenalainen, koska kasvuerot yleensä kompensoituvat eläimen kasvaessa. Hiehojen ruokinnassakin karkearehun laadulla on vaikutus valkuaislisän tarpeellisuuteen. Jos peruskarkearehuna on hyvälaatuinen nurmisäilörehu ei valkuaislisän käytölle näyttäisi olevan perusteita.

Ruokinta vaikutti myös jonkin verran eläinten ruumiin muotojen kehitykseen. Selvimmin erot olivat nähtävissä rinnanympäryksen mittaustuloksissa (Taulukko 5). Yhdeksän kuukauden iästä saakka MH4ryhmän hiehoilla oli merkitsevästi suurempi rinnanympärysmitta kuin MH2- tai OHRA2-ryhmän hiehoilla $(\mathrm{P}<0.001)$. MH2- ja OHRA2-ryhmien välillä ei ollut eroa rinnanympärysmitoissa. Myös säkäkorkeuksissa ja ruumiin pituudessa esiintyi hieman eroja kokeen aikana, mutta nämä eroavaisuudet tasoittuivat kokeen aikana, eikä kokeen loppupuolella eroja enää esiintynyt (Taulukko 5).

Taulukko 5. Hiehojen elopainon, säkäkorkeuden, rinnanympäryksen ja pituuden kehitys kokeen aikana.

\begin{tabular}{|c|c|c|c|c|c|}
\hline & OHRA2 & MH2 & MH4 & $\mathrm{SEE}^{1)}$ & $\begin{array}{c}\text { Tilastollinen } \\
\text { merkitsevyys }\end{array}$ \\
\hline \multicolumn{6}{|l|}{ Hiehojen elopaino, kg } \\
\hline - $\quad$ alussa (3 kuukauden iässä) & 89 & 89 & 86 & 6,6 & \\
\hline - $\quad 6$ kuukauden iässä & $124^{\mathrm{a}}$ & $130^{\mathrm{a}}$ & $136^{\mathrm{b}}$ & 9,6 & $* *$ \\
\hline - 9 kuukauden iässä & $205^{\mathrm{a}}$ & $213^{\mathrm{a}}$ & $246^{\mathrm{b}}$ & 8,8 & $* * *$ \\
\hline - $\quad 12$ kuukauden iässä & $328^{\mathrm{a}}$ & $331^{\mathrm{a}}$ & $378^{b}$ & 14,0 & $* * *$ \\
\hline - $\quad 14$ kuukauden iässä & $396^{\mathrm{a}}$ & $399^{\mathrm{a}}$ & $449^{b}$ & 17,3 & $* * *$ \\
\hline \multicolumn{6}{|l|}{ Säkäkorkeus, cm } \\
\hline - $\quad$ alussa (3 kuukauden iässä) & 88 & 85 & 85 & 2,6 & \\
\hline - $\quad 6$ kuukauden iässä & $98^{\mathrm{ab}}$ & $97^{\mathrm{a}}$ & $99^{\mathrm{b}}$ & 2,2 & $*$ \\
\hline - 9 kuukauden iässä & $105^{\mathrm{ab}}$ & $104^{\mathrm{a}}$ & $107^{\mathrm{b}}$ & 2,7 & * \\
\hline - $\quad 12$ kuukauden iässä & 117 & 118 & 117 & 3,1 & \\
\hline - $\quad 14$ kuukauden iässä & 122 & 123 & 122 & 3,7 & \\
\hline \multicolumn{6}{|l|}{ Rinnan ympärys, cm } \\
\hline - $\quad$ alussa (3 kuukauden iässä) & 99 & 97 & 97 & 3,3 & \\
\hline - $\quad 6$ kuukauden iässä & 113 & 112 & 114 & 4,1 & \\
\hline - $\quad 9$ kuukauden iässä & $136^{\mathrm{a}}$ & $135^{\mathrm{a}}$ & $140^{\mathrm{b}}$ & 3,3 & $* * *$ \\
\hline - $\quad 12$ kuukauden iässä & $160^{\mathrm{a}}$ & $159^{\mathrm{a}}$ & $165^{b}$ & 3,4 & $* * *$ \\
\hline - $\quad 14$ kuukauden iässä & $173^{\mathrm{a}}$ & $173^{\mathrm{a}}$ & $182^{\mathrm{b}}$ & 4,1 & $* * *$ \\
\hline \multicolumn{6}{|l|}{ Pituus, cm } \\
\hline - $\quad$ alussa (3 kuukauden iässä) & 79 & 79 & 78 & 2,4 & \\
\hline - $\quad 6$ kuukauden iässä & $91^{\mathrm{a}}$ & $91^{\mathrm{a}}$ & $95^{\mathrm{b}}$ & 2,7 & $* * *$ \\
\hline - 9 kuukauden iässä & $101^{\mathrm{a}}$ & $103^{\mathrm{a}}$ & $106^{\mathrm{b}}$ & 2,4 & $* * *$ \\
\hline - $\quad 12$ kuukauden iässä & $119^{\mathrm{a}}$ & $122^{b}$ & $122^{\mathrm{b}}$ & 2,1 & $* *$ \\
\hline - $\quad 14$ kuukauden iässä & 124 & 125 & 126 & 3,0 & \\
\hline
\end{tabular}


Taulukosta 6 käyvät ilmi hiehojen kasvu-, rehun hyväksikäyttö- ja teurastulokset eri ruokintaryhmissä sekä ruokintojen näennäinen in vivo -sulavuus. Hiehojen keskimääräinen päiväkasvu kokeen aikana oli $942 \mathrm{~g} / \mathrm{pv}$ ja nettokasvu puolestaan $488 \mathrm{~g} / \mathrm{pv}$. Tulokset olivat hyviä puhtaasti maitorotuisille eläimille, sillä keskimääräiset kasvut ovat jopa parempia kuin mitä joissakin aiemmissa kokeissa on saavutettu liharoturisteytyseläimillä (Rinne ym. 1998, Rinne ja Ojajärvi 1998, Manninen ym. 2002).

Väkirehuruokinnan voimakkuus vaikutti selkeästi kasvutuloksiin, sillä MH4-ryhmän hiehot kasvoivat selkeästi paremmin kuin MH2- tai OHRA2-ryhmän hiehot $(\mathrm{P}<0.001)$. MH2- ja OHRA2ryhmien välillä ei ollut merkitseviä eroja kasvuluvuissa. Rehun hyväksikäyttöön ruokinnoilla ei ollut vaikutusta. Keskimäärin rehua kului kokeen aikana 13,2 kg ka nettokasvukiloa kohti.

Hiehojen keskimääräinen teuraspaino oli 231 kilogrammaa. Teurastusten porrastuksesta huolimatta MH2-ryhmän teuraspaino jäi 11 kilogrammaa matalammaksi kuin MH4-ryhmällä. Kaikilla ruokinnoilla päästiin kuitenkin tavoiteltuun teuraspainohaarukkaan (220-240 kg). Toteutunut teurasprosentti oli keskimäärin 49,9. MH2-ryhmän hieman matalammaksi jäänyt teuraspaino näkyi ilmeisesti ruhojen EUROP-luokituksessa, sillä sekä lihakkuus että rasvaisuus olivat pienimmät MH2-ruokinnalla. Ruhojen rasvaisuudessa ei tosin ollut merkitseviä eroja ruokintojen välillä, mutta lihakkuudessa MH4-ruokinta oli jonkin verran $\mathrm{MH2}$-ruokintaa parempi $(\mathrm{P}<0.01)$. Väkirehun päivittäisen annosmäärän nostaminen 2 kilogrammasta 4 kilogrammaan ei siten tässä tutkimuksessa vaikuttanut ruhojen rasvoittumiseen. Ruokinnan väkirehuprosentti oli kokeen aikana OHRA2- ja MH2-ruokinnoilla keskimäärin 35 \% ja MH4ruokinnalla $50 \%$.

Taulukko 6. Hiehojen kasvu-, rehun hyväksikäyttö- ja teurastulokset sekä ruokintojen näennäinen in vivo-sulavuus ruokintaryhmittäin.

\begin{tabular}{|c|c|c|c|c|c|}
\hline & OHRA2 & MH2 & MH4 & $S_{E E}{ }^{1)}$ & $\begin{array}{c}\text { Tilastollinen } \\
\text { merkitsevyys }^{2)}\end{array}$ \\
\hline \multicolumn{6}{|l|}{ Hiehojen kasvu, g/pv } \\
\hline - $\quad$ nettokasvu kokeen aikana & $456^{\mathrm{a}}$ & $471^{\mathrm{a}}$ & $541^{b}$ & 43,3 & $* * *$ \\
\hline - $\quad$ nettokasvu 2 vk -teurastus & $418^{\mathrm{a}}$ & $431^{\mathrm{a}}$ & $487^{\mathrm{b}}$ & 29,2 & $* * *$ \\
\hline - $\quad$ päiväkasvu kokeen aikana & $876^{\mathrm{a}}$ & $901^{\mathrm{a}}$ & $1065^{b}$ & 78,7 & $* * *$ \\
\hline \multicolumn{6}{|l|}{ Rehun hyväksikäyttö } \\
\hline - $\quad$ kg ka / nettokasvukilo & 13,22 & 13,13 & 13,22 & 1,082 & \\
\hline - $\quad$ ry / nettokasvukilo & 12,95 & 12,58 & 13,08 & 1,037 & \\
\hline \multicolumn{6}{|l|}{ Teurastulokset } \\
\hline - $\quad$ teuraspaino, kg & $232^{\mathrm{ab}}$ & $225^{\mathrm{a}}$ & $236^{b}$ & 7,5 & $*$ \\
\hline - $\quad$ teurasprosentti & 50,2 & 50,1 & 49,2 & 1,39 & \\
\hline - $\quad$ lihakkuus (EUROP) $^{3)}$ & $3,44^{\mathrm{ab}}$ & $3,00^{\mathrm{a}}$ & $3,76^{b}$ & 0,410 & $* *$ \\
\hline rasvaisuus (EUROP) ${ }^{4)}$ & 3,56 & 3,31 & 3,41 & 0,680 & \\
\hline \multicolumn{6}{|l|}{$\begin{array}{l}\text { Ruokintojen näennäinen in vivo - } \\
\text { sulavuus, g/kg }\end{array}$} \\
\hline - $\quad$ kuiva-aine & $751^{\mathrm{a}}$ & $724^{b}$ & $730^{\mathrm{ab}}$ & 22,6 & $*$ \\
\hline - $\quad$ orgaaninen aine & $769^{\mathrm{a}}$ & $739^{b}$ & $748^{\mathrm{ab}}$ & 22,5 & $*$ \\
\hline - $\quad$ raakavalkuainen & 752 & 739 & 749 & 24,0 & \\
\hline - $\quad$ NDF-kuitu & $706^{\mathrm{a}}$ & $667^{\mathrm{ab}}$ & $621^{b}$ & 36,5 & $* * *$ \\
\hline
\end{tabular}

1) Estimaatin keskivirhe. ${ }^{2)}$ Tilastollinen merkitsevyys: ${ }^{*} \mathrm{p}<0,05 ; * * \mathrm{p}<0,01$; ${ }^{* * *} \mathrm{p}<0,001$. Tilastollisesti merkitsevät erot on ilmoitettu eri yläindekseillä. ${ }^{3)}$ EUROP-luokitus: $\mathrm{P}-=1, \mathrm{P}=2, \mathrm{P}+=3$, O- = 4, O = 5, O+ = 6. ${ }^{4)}$ EUROPluokitus: 1 = rasvaton, 2 = ohutrasvainen, 3 = keskirasvainen, 4 = rasvainen, 5 = erittäin rasvainen.

Ruokintojen sulavuudessa oli myös joitakin eroavuuksia ruokintojen välillä (Taulukko 5). Selvimmin erot näkyivät NDF-kuidun sulavuudessa, joka oli heikoin voimakkaimmalla väkirehuruokinnalla. Merkittävimpänä syynä tähän on se, että hiehot söivät MH4-ruokinnalla toisia ruokintoja enemmän väkirehua ja vähemmän säilörehua. Väkirehun kuitu on säilörehun kuitua heikommin sulavaa. Toisena syynä lienee kuidun sulatusnopeuden hidastuminen pötsin pH:n laskun seurauksena voimakkaammalla väkirehuruokinnalla (Huhtanen ja Jaakkola 1993). Tämä johtuu siitä, että happamuus inhiboi pötsin sellulolyyttisten mikrobien toimintaa. 


\section{Johtopäätökset}

Hiehojen päivittäisen väkirehuannoksen nostaminen kahdesta kilogrammasta neljään kilogrammaan lisäsi eläinten kuiva-aineen syöntiä ja energian saantia. Väkirehuannoksen lisäys tarkoitti käytännössä ruokinnan väkirehuprosentin nostamista 35 \%:sta 50 \%:iin. Hiehojen kasvutulokset paranivat energian saannin lisääntyessä, mutta voimakkaampi ruokinta ei lisännyt ruhojen rasvoittumista. Hiehot olivat suhteellisen rasvaisia (EUROP-keskimäärin 3-4), verrattaessa aikaisempiin kokeisiin, joissa hiehot on teurastettu matalammissa painoissa.

\section{Kirjallisuus}

Ahvenjärvi, S., Vanhatalo, A., Huhtanen, P. \& Varvikko, T. 2000. Determination of reticulo-rumen and stomach digestion in lactating cows by omasal canal and duodenal sampling. British J. Nutr. 83: 67-77.

Foldager, J. \& Sejrsen, K. 1991. Rearing intensity in heifers and the effect on subsequent milk production. Report no 693 from Natl. Inst. Anim. Sci. Denmark, 131 pp.

Huhtanen, P. \& Jaakkola, S. 1993. The effects of forage preservation method and proportion of concentrate on digestion of cell wall carbohydrates and rumen digesta pool size in cattle. Grass and Forage Sci. 48: 155-165.

Huhtanen, P., Khalili, H., Nousiainen, J.I., Rinne, M., Jaakkola, S., Heikkilä, T. \& Nousiainen, J. 2002. Prediction of the relative intake potential of grass silage by dairy cows. Livest. Prod. Sci. 73: 111-130.

Keulen, J. van \& Young, B.A. 1977. Evaluation of acid-insoluble ash a marker in ruminant digestibility studies. J. Anim. Sci. 44: 282-287.

Manninen, M., Aronen, I., Puntila, M.-L., Heikkilä, R. \& Jaakkola, S. 1998. Effect of type of forage offered and breed on performance of crossbred suckler heifers and their calves. Agric. Food Sci. Finland 7, 3: 367-380.

Manninen, M., Ojajärvi, P. \& Suvitie, M. 2004. Kaura-rehuvirnasäilörehu teurashiehojen ruokinnassa. In: Toim. Anneli Hopponen ja Marketta Rinne. Maataloustieteen Päivät 2004, 12.-13.1.2004 Viikki, Helsinki. Suomen maataloustieteellisen seuran tiedote 19: 4 p.

Manninen, M., Virkajärvi, P., Ojajärvi, P., Jauhiainen, L. \& Suvitie, M. 2002. Toisen laidunkauden vaikutus teuraaksi kasvatettavien hf-hiehojen kasvuun sekä ruhon ja lihan laatuun. In: toim. Marketta Rinne. Maataloustieteen Päivät 2002: Kotieläintiede, 9.-10.2002, Viikki, Helsinki. Maaseutukeskusten Liiton julkaisuja 977: p. 188-191.

Moisio, T. \& Heikonen, M. 1989. A titration method for silage assessment. Anim. Feed Sci. Technol. 22: 341-353. Mäntysaari, P. 1993. The effects of feeding level and protein source of the diet on growth and development at slaughter of pre-pubertal heifers. Acta Agric. Scand. Sect. A. Animal. Science 43 (1): 44-51.

Mäntysaari, P. 2001. Effect of feeding before puberty and during gestation on milk production potential and body development of dairy replacement heifers. Helsingin yliopiston kotieläintieteen laitoksen julkaisuja 60: 44 s. + encl.. Diss.: Helsingin yliopisto, 2001. (väitöskirja).

Nousiainen, J., Ahvenjärvi, S., Rinne, M., Hellämäki, M. \& Huhtanen, P. 2004. Prediction of indigestible cell wall fraction of grass silage by near infrared reflectance spectroscopy. Anim. Feed Sci. Technol. 115: $295-311$.

Raussi, S., Boissy, A., Delval, E., Pradel, P., Kaihilahti, J. \& Veissier, I. 2005. Does repeated regrouping alter the social behaviour of heifers? Appl. Anim. Behav. Sci. 93: 1-12.

Rinne, M., Harinen, T., Asikainen, U., Huhta, H. ja Aspila, P. 1998. Ruokinnan voimakkuuden vaikutus teurashiehojen kasvuun. In: Kotieläintieteen päivät 1998. Maaseutukeskusten Liiton julkaisuja 924: p. 293-296.

Rinne, M. \& Ojajärvi, P. 1998. Ohra tai rypsirouhe rajoitetusti säilörehua saaneiden teurashiehojen väkirehuna. In: Kotieläintieteen päivät 1998. Maaseutukeskusten Liiton julkaisuja 924: p. 297-302.

Sejrsen, K., Huber, J.T., Tucker, H.A. \& Akers, R.M. 1982. Influence of nutrition on mammary development in pre- and post-pubertal heifers. J. Dairy Sci. 65: 793-800.

Suvitie, M. \& Manninen, M. 1992. Risteytyshiehot lihantuottajina. Koetoiminta ja käytäntö 49: p. 19.

Tuori, M. 1992. Rapeseed meal as a supplementary protein for dairy cows on grass silage-based diet, with the emphasis on the Nordic AAT-PBV feed protein evaluation system. Agric. Sci. Fin. 1: 369-439.

Tuori, M., Kaustell, K., Valaja, J., Aimonen, E., Saarisalo, E. \& Huhtanen, P. 2000. Rehutaulukot ja ruokintasuositukset. Helsinki: Yliopistopaino. $88 \mathrm{~s}$. 